\title{
1989 WORLD MICROCOMPUTER CHESS CHAMPIONSHIP
}

\author{
ICCA Communication \\ by David Levy
}

This event will take place in Portoroz, in northern Yugoslavia, from September $9^{\text {th }}$ to $16^{\text {th }}$. Play will be in the ballroom of the Palace Hotel, where in 1958 a young American called Bobby Fischer played in his first international tournament. The participants and officials will stay at the Grand Hotel Palace, which is next door to the Palace Hotel.

There will be 7 playing days. There will be a free day for an excursion to the local caves, which are world famous, and on the evening of the free day there will be a match between a team of computers from the event and a team from the Portoroz Chess Club.

Since chess is enormously popular in Yugoslavia we expect the event to receive considerable publicity, including nation-wide TV coverage. The local organizers are the Tourist Office Portoroz.

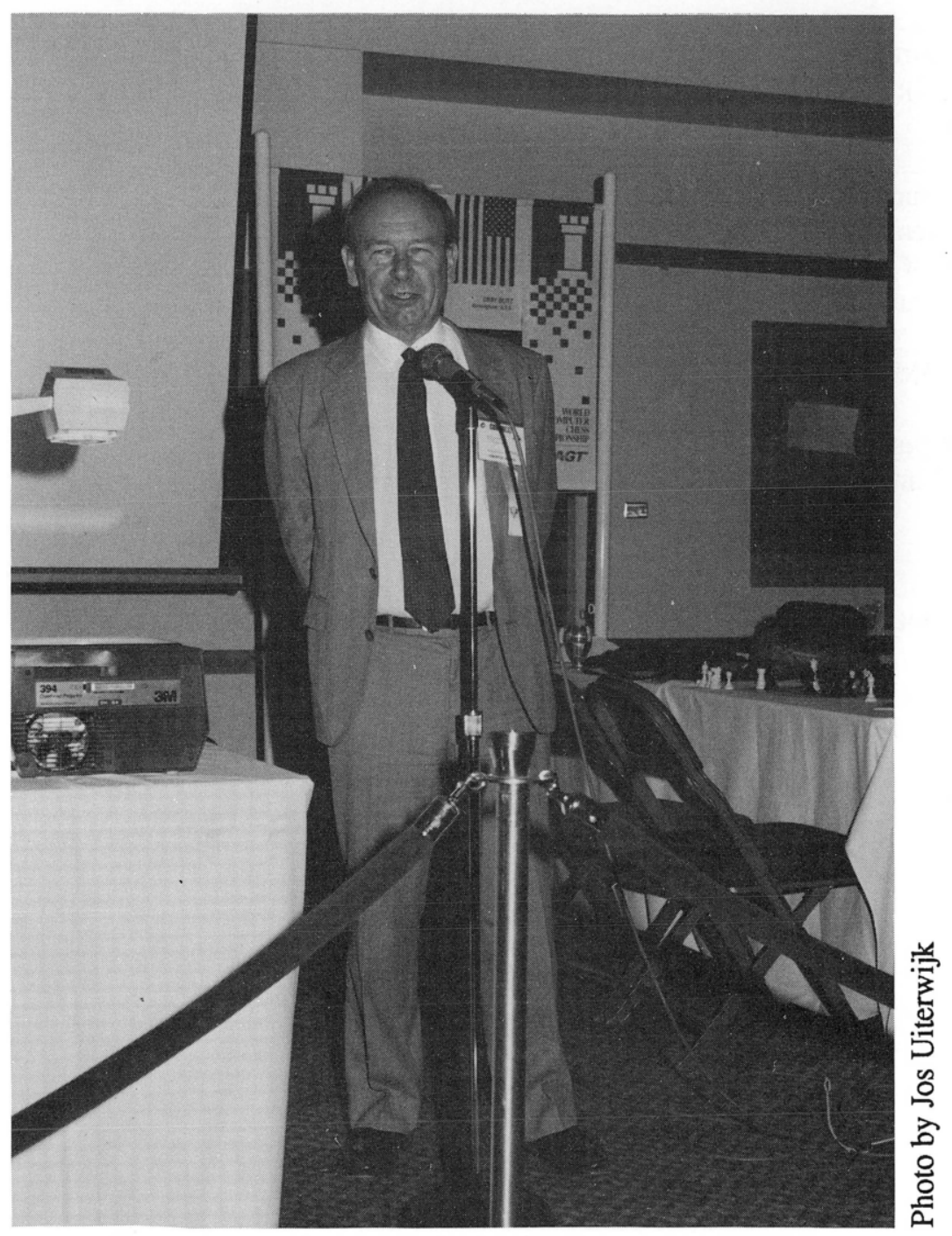

Professor Donald Michie: intelligent chess comments invited, but keep it human. 


\section{ENTRY FORM - WORLD MICROCOMPUTER CHESS CHAMPIONSHIP}

\section{PORTOROZ, YUGOSLAVIA}

September $9^{\text {th }}-16^{\text {th }}, 1989$

Author(s) of the program:

Name and address for correspondence:

Work telephone: Home telephone:

Name of program: Number of games played:

Tournament record:

Programming language: Size of program:

Size of openings book (positions):

Hardware being used in the tournament:

Microprocessor(s):

Which of the authors will come to Portoroz? Clock speed:

\section{FOR MANUFACTURERS' GROUP ONLY}

The above information must be supplied for all of your machines except a machine in the "unlimited" category.

How many machines are you entering? (delete as applicable) $\begin{array}{llll}1 & 2 & 3 & 4\end{array}$ Is one of these machines in the unlimited category? YES NO

Total entry fee: $\$$

Note that manufacturers who enter the unlimited category must pay $\$ 4,000$ U.S. irrespective of whether they enter $0,1,2$ or 3 additional machines. Other manufacturers must pay $\$ 1,000$ per machine. Non-Amateurs in the software group must pay $\$ 1,000$ (only one machine allowed). Amateurs must pay $\$ 250$.

Date of entry: Signature:

At the discretion of the ICCA certain amateur programmers may receive free hotel room and food. Also, the local organizers are trying to negotiate reduced air travel on JAT (Yugoslav Airlines).

Entries and enquiries should be addressed to:

\section{David Levy}

11, Loudoun Road London NW8 0LP

England
telephone:
(1) $624-5551$
fax:
(1) $372-3266$
telex: 939002 ICHESS G

Entries should arrive not later than July $26^{\text {th }}$ (Manufacturers' Group) or August $26^{\text {th }}$ (Software Group). 